\title{
Kelelahan Mata dan Keluhan MSDs Perkuliahan Daring Selama Pandemi COVID-19 pada Mahasiswa di Tiga Fakultas Universitas Sari Mulia (Program Studi Teknik Industri, D-IV Promosi Kesehatan dan Program Studi Manajemen)
}

\author{
Madschen Sia Mei Ol Siska Selvija Tambun ${ }^{1 *}$, Husda Oktaviannoor ${ }^{2}$ \\ 1Teknik Industri Universitas Sari Mulia Banjarmasin \\ ${ }^{2}$ D-IV Promosi Kesehatan Universitas Sari Mulia Banjarmasin \\ Jl. Pramuka No.2, Pemurus Luar, Banjarmasin, Kalimantan Selatan, 70238, Indonesia \\ 1*marunehutabarat10041979@gmail.com \\ 2husda.oktaviannoor@gmail.com

\section{Visual Fatigue and MSDs Complaints Online Learning during The COVID-19 Pandemic on Students in Three Faculty Sari Mulia University (Industrial Engineering, D-IV Health Promotion and Management)}

Dikirimkan : 05, 2021. Diterima : 08, 2021. Dipublikasikan : 09, 2021

\begin{abstract}
The spread of COVID-19 cases is very fast, affecting all sectors. One of these sectors is educational institutions. In order for the learning process to continue, an online learning system was implemented. Online learning causes an increase in sitting rather than standing, activity in front of a smartphone or laptop. The purpose of this study is to identify eye fatigue and MSDs complaints in students at three study programs, Industrial Engineering, DIV-Health Promotion and Management. The data was collected through an online survey of students. This study used a descriptive analysis research design with a cross sectional approach with the number of respondents 55 students. The results showed that eye fatigue was mostly experienced with sore eyes as many as 35 students (63.63\%). Then followed by headaches as many as 34 people (61.81\%) and watery eyes as many as 23 people (41.81\%). Meanwhile, the majority of MSDs complaints among students were at the waist as many as 34 people (61.8\%), on the upper neck as many as 33 people (60\%) and on the lower neck as many as 25 people (45.5\%).
\end{abstract}

Keywords-Online Learning, Visual Fatigue, MSDs Complaints, Nordic Body Map

\begin{abstract}
Abstrak- Penyebaran yang kasus COVID-19 yang sangat cepat, berdampak terhadap semua sektor. Salah satu sektor tersebut adalah institusi pendidikan. Agar proses pembelajaran tetap berjalan, maka dilaksanakan sistem pembelajaran daring. Pembelajaran daring menyebabkan terjadinya peningkatan aktivitas duduk daripada berdiri, aktivitas di depan smartphone atau laptop. Selain itu, pembelajaran daring dapat meningkatkan kelelahan mata karena aktivitas di depan smartphone atau laptop. Tujuan dari penelitian ini yaitu mengidentifikasi kelelahan mata dan keluhan MSDs pada mahasiswa di tiga program studi yaitu Program Studi Teknik Industri, Program Studi DIV-Promosi Kesehatan dan Program Studi Manajemen. Pengumpulan data dilakukan melalui survei secara daring terhadap mahasiswa. Penelitian ini menggunakan desain penelitian analisis deskriptif dengan pendekatan cross sectional dengan jumlah responden 55 orang mahasiswa. Hasil
\end{abstract}


penelitian didapatkan keluhan kelelahan mata yang paling banyak dialami oleh responden adalah mata perih sebanyak 35 orang mahasiswa $(63,63 \%)$. Kemudian diikuti keluhan sakit kepala sebanyak 34 orang $(61,81 \%)$ dan mata berair sebanyak 23 orang (41,81\%). Sedangkan untuk keluhan MSDs pada mahasiswa adalah mayoritas pada bagian pinggang sebanyak 34 orang $(61,8 \%)$, pada bagian leher atas sebanyak 33 orang $(60 \%)$ dan pada bagian leher bawah sebanyak 25 orang $(45,5 \%)$.

Kata kunci- Pembelajaran Daring, Kelelahan Mata, Keluhan MSDs, Nordic Body Map (NBM).

\section{PENDAHULUAN}

Badan Kesehatan Dunia (WHO) secara resmi menyatakan bahwa COVID-19 menjadi pandemi global. Hal ini didasarkan atas meningkatnya jumlah kasus di luar China hingga 13 kali lipat serta banyaknya negara yang terinfeksi. Peningkatan jumlah kasus berlangsung cukup cepat, dan menyebar ke berbagai negara dalam waktu singkat [1]. Penyebaran yang kasus COVID-19 yang sangat cepat, berdampak terhadap semua sektor. Salah satu sektor tersebut adalah institusi pendidikan untuk menghentikan kerumunan massa (seperti aktivitas perkuliahan) dalam rangka menekan jumlah infeksi dan penyebaran kasus COVID-19. Beberapa universitas di Indonesia, Malaysia dan beberapa negara lain sudah mulai mengantisipasi penyebaran COVID-19 dengan melaksanakan sistem pembelajaran daring [2]. Pembelajaran daring menyebabkan terjadinya peningkatan aktivitas duduk daripada berdiri, aktivitas di depan smartphone atau laptop. Selain itu, pembelajaran daring dapat meningkatkan kelelahan mata karena aktivitas di depan smartphone atau laptop.

Pada penelitian Wahyuningtyas, et al (2019), perubahan aktivitas pada mahasiswa selama pandemi COVID-19 dapat memberikan dampak yang negatif. Jika kita melihat penelitian terdahulu, mahasiswa Teknik Informatika Universitas Muhammadiyah Ponogoro mengalami keluhan $M S D s$ pada leher bagian bawah, punggung atas dan punggung bawah akibat terlalu lama beraktivitas di depan laptop Aktivitas yang dominan di depan laptop dan komputer merupakan salah satu penyebab kejadian Musculoskeletal Disorders $(M S D s)$ pada mahasiswa yaitu posisi penggunaan laptop yang tidak ergonomis. Mahasiswa pada saat penggunaan laptop dengan posisi yang tidak ergonomis seperti posisi membungkuk ke depan dan terlalu condong ke kanan atau ke kiri sehingga mahasiswa banyak yang mengeluh nyeri, kesemutan sampai mati rasa pada leher, bahu, tangan, jari-jari tangan, punggung, dan kaki saat menggunakan laptop dalam durasi yang lama dengan posisi statis. Sebuah studi yang dilakukan oleh Traker melaporkan bahwa penggunaan komputer tablet yang merupakan layar dengan tampilan visual kecil dapat mengakibatkan fleksi serviks yang lebih besar dibandingkan dengan penggunaan komputer dengan desktop besar dan meningkatkan aktivitas otot di sekitar bahu [3].

Apabila postur ini tetap dipertahankan dalam jangka waktu lama maka tidak hanya menimbulkan kesakitan di area leher dan punggung, akan tetapi merusak indra proprioseptif [4]. Demikian juga sama halnya dengan penggunaan smartphone. Dengan pemakaian smartphone yang semakin meningkat, maka waktu yang dihabiskan penggunaan smartphone juga semakin meningkat. Menggunakan smartphone dalam waktu yang lama dapat menyebabkan sakit leher dan punggung [5]. Ketika menggunakan smartphone juga akan berpengaruh terhadap bagian leher. Leher dan bahu adalah area yang mudah terasa sakit selama penggunaan smartphone dan menyebabkan kelelahan otot yang tinggi sehingga timbullah nyeri [4]. Mahasiswa di tiga prodi Universitas Sari Mulia Banjarmasin menggunakan laptop maupun smartphone dalam mengikuti perkuliahan online setiap harinya, mengerjakan tugas, bersosialisasi di media sosial dan bermain Games. Penggunaan laptop maupun smartphone setiap hari dalam waktu yang lama sera posisi yang tidak ergonomis. Durasi dan penggunaan laptop maupun smartphone dalam waktu $\geq 4$ jam per hari dengan posisi duduk membungkuk, duduk di lantai sering kali berisiko mengalami keluhan kesehatan terkait penggunaan laptop maupun smartphone yaitu MSDs.

Penelitian sebelumnya yang dilakukan pada 14 orang dewasa muda yang sehat dan terdaftar di Universitas Chungbuk U1 sudah mencakup aktivitas otot ekstremitas atas, terdapat nyeri selama penggunaan smartphone dan waktu yang dihabiskan untuk pemakaian smartphone [4]. Selain itu, mahasiswa yang terus-menerus di depan laptop juga mengalami keluhan mata kering dan mata lelah [5]. Rabun jauh (miopia) dan keluhan sakit kepala juga terjadi pada mahasiswa karena intensitas penggunaan smartphone yang terus-menerus [6]. Menatap secara terus menerus pada layar smartphone juga dapat mengakibatkan gangguan kesehatan seperti migrain, lingkaran hitam di bawah mata, penglihatan terganggu, sakit pada kepala dan leher, pengacauan pada sistem otak. Secara harafiah mengarah kepada penglihatan, otot dan lelah otot. Cahaya biru pada smartphone dapat menyebabkan peningkatan kelelahan sehingga berakibat pada gangguan pola tidur, merasa lemas, penglihatan kabur atau berkurang, sakit mata, sakit kepala, mengurangi hormon melatonin dan banyak masalah kesehatan lainnya [7].

Istilah ergonomi berasal dari bahasa Yunani yang terdiri dua kata yaitu "ergon" berarti kerja dan "nomos" berarti aturan atau hukum. Ergonomi adalah suatu aturan atau norma dalam sistem kerja. 
Di Indonesia memakai istilah ergonomi dan di beberapa negara seperti di Skandinavia menggunakan istilah "Bioteknologi" sedangkan di negara Amerika menggunakan istilah "Human Engineering" atau "Human Factors Engineering" [8].

Pengetahuan ergonomi pada mahasiswa sangat diperlukan, karena pada umumnya ergonomi membahas interaksi antara manusia, pekerjaan dan peralatan yang digunakan untuk menunjang pekerjaan. Dengan adanya pengetahuan ergonomi yang baik dari mahasiswa, maka diharapkan akan terciptanya lingkungan kerja yang nyaman kecelakaan dan penyakit akibat kerja menurun sehingga produktivitas dari seluruh pekerjaan dapat maksimal.

Untuk pengukuran keluhan MSDs dengan menggunakan Kuesioner Nordic Body Map (NBM). Nordic Body Map merupakan merupakan salah satu metode pengukuran subjektif untuk mengukur rasa sakit otot para pekerja. Kuesioner Nordic Body Map merupakan salah satu bentuk kuesioner checklist ergonomi. Kuesioner Nordic Body Map adalah kuesioner yang paling sering digunakan untuk mengetahui ketidaknyamanan pada para pekerja karena sudah terstandarisasi dan tersusun rapi [8].

Untuk memperoleh gambaran keluhan MSDs menggunakan Nordic Body Map terdapat tingkat keluhan mulai dari agak sakit, sakit, hingga sangat sakit. Hasil dari penggunaan Nordic Body Map juga dapat melihat dan mengestimasi tingkat keluhan yang dirasakan oleh pekerja. Pengisian kuesioner Nordic Body Map ini bertujuan untuk mengetahui bagian tubuh dari pekerja yang terasa sakit sebelum dan sesudah melakukan pekerjaan pada stasiun kerja [8].

Kelelahan mata adalah ketegangan pada mata atau visual yang disebabkan oleh penggunaan indra penglihatan dalam pekerjaan yang membutuhkan kemampuan untuk melihat pada jangka waktu yang lama, disertai dengan kondisi pandangan yang tidak nyaman [9]. Selain itu, kelelahan mata dapat timbul sebagai stres mendalam atau intensif pada fungsi mata seperti otot-otot akomodasi yang bekerja memerlukan pengamatan secara teliti atau terhadap retina sebagai akibat ketidaktepatan kontras/ pencahayaan [10].

Kelelahan otot dan saraf pada mata terjadi sebagai akibat tegangan yang terus-menerus. Namun tidak menyebabkan kerusakan mata secara permanen, tetapi menambah beban kerja, cepat lelah, hilangnya jam kerja, sering istirahat, kepuasan kerja berkurang, mutu produksi mengalami penurunan, frekuensi kesalahan yang meningkat, konsentrasi menjadi terganggu dan menurunkan produktivitas kerja [9].

Hasil survei pada responden menunjukkan dalam mengikuti perkuliahan daring menggunakan laptop maupun smartphone. Dari survei awal yang telah dilakukan pada Bulan Februari 2021, masih terdapat posisi mahasiswa yang tidak ergonomis dalam mengikuti perkuliahan daring sehingga menimbulkan keluhan pada beberapa bagian tubuh. Selain mengikuti perkuliahan daring, pemakaian laptop maupun smartphone digunakan untuk melakukan aktivitas lain seperti mengakses Youtube, bermain Gamess, berselancar di media sosial sehingga bisa meningkatkan kelelahan mata pada mahasiswa. Berdasarkan hal tersebut, maka tujuan dari penelitian ini yaitu mengidentifikasi kelelahan mata dan keluhan MSDs pada mahasiswa di tiga program studi yaitu Program Studi Teknik Industri, DIV-Promosi Kesehatan dan Manajemen.

\section{METODOLOGI PENELITIAN}

Pengumpulan data dilakukan melalui survei secara daring terhadap mahasiswa di tiga program studi yaitu Program Studi Teknik Industri, Program Studi DIV-Promosi Kesehatan dan Program Studi Manajemen Universitas Sari Mulia Banjarmasin. Secara keseluruhan mahasiswa aktif mengikuti perkuliahan daring. Penelitian ini menggunakan pendekatan kuantitatif deskriptif untuk melihat gambaran keluhan MSDs dan kelelahan mata. Sampel pada penelitian ini berjumlah 55 orang responden. Apabila jumlah sampel kurang dari 100, maka sampel diambil secara keseluruhan. Karena jumlah sampel ini kurang dari 100 orang maka digunakan metode total sampling [11]. Pelaksanaan survei pada Bulan Maret 2021. Pertanyaan kuesioner terdiri dari karakteristik responden, perilaku selama mengikuti perkuliahan daring, kelelahan mata dan keluhan MSDs. Gangguan musculoskeletal mencakup berbagai macam kondisi yang mempengaruhi sistem musculoskeletal termasuk sendi, otot, tendon, liGamesn, saraf tepi, dan mendukung pembuluh darah. MSDs bersifat inflamasi dan bersifat degeneratif dengan gejala seperti nyeri, mati rasa, kesemutan, sakit, kaku, atau terbakar [12]. Indikator keluhan MSDs yang digunakan adalah kuesioner Nordic Body Map (NBM).

Pada kuesioner Nordic Body Map berdasarkan [13], skor yang digunakan tingkat keluhan mulai dari agak sakit yang berarti dirasakan sedikit adanya keluhan atau kenyerian pada bagian otot, tetapi belum mengganggu pekerjaan, sakit yang berarti responden merasakan adanya keluhan/kenyerian atau sakit pada bagian otot dan sudah mengganggu pekerjaan, tetapi rasa kenyerian segera hilang setelah dilakukan istirahat dari pekerjaan dan sangat sakit yang berarti responden merasakan keluhan sangat sakit atau sangat nyeri 
pada bagian otot dan kenyerian tidak segera hilang meskipun telah beristirahat yang lama atau bahkan diperlukan obat pereda nyeri otot [12].
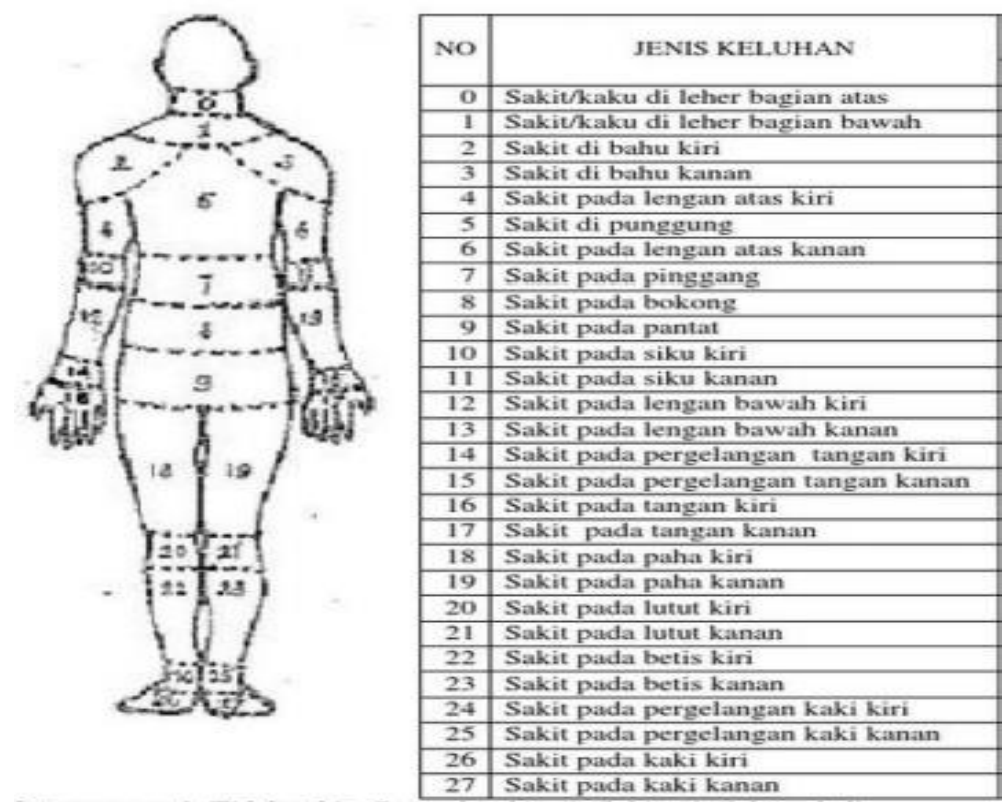

Gambar 1. Nordic body map
Kelelahan mata dapat diketahui dengan menanyakan keluhan yang dialami responden melalui kuesioner yang dibagi [14]. Penilaian kelelahan mata didasarkan pada jawaban yang diisi pekerja. Keluhan kelelahan mata dapat dibagi menjadi dua kategori yaitu kelelahan mata ringan jika responden atau pekerja mengalami keluhan mata terasa perih, mata berair, dan mata merah. Kelelahan mata berat jika responden atau pekerja mengalami keluhan kelelahan mata ringan juga disertai dengan keluhan nyeri di sekitar mata, penglihatan kabur, penglihatan ganda, sulit fokus dalam melihat, sakit kepala, dan pusing yang disertai mual [14].

\section{HASIL PENELITIAN}

Karakteristik mahasiswa sebagai responden penelitian selama mengikuti perkuliahan daring dapat dilihat pada Tabel I. Dari Tabel I dapat terlihat bahwa jumlah mahasiswa laki-laki ada sebanyak 13 orang $(23,63 \%)$ dan mahasiswa perempuan ada 42 orang $(76,36 \%)$. Dari segi umur, responden paling banyak umur 19 tahun sebanyak 21 orang mahasiswa $(38,18 \%)$. Mahasiswa yang melakukan perkuliahan daring paling banyak di Kota Banjarmasin ada sebanyak 40 orang $(72,72 \%)$. Dan angkatan yang paling banyak mengikuti perkuliahan daring berasal dari angkatan 2020 sebanyak 29 orang mahasiswa $(52,72 \%)$ dan diikuti angkatan 2019 sebanyak 26 orang mahasiswa $(52,72 \%)$.
TABEL I

DISTRIBUSI DAN FREKUENSI KARAKTERISTIK RESPONDEN

\begin{tabular}{|c|c|c|c|c|c|}
\hline Variabel & $\underset{\text { ah }}{\text { Juml }}$ & $\%$ & Variabel & $\begin{array}{c}\text { Juml } \\
\text { ah }\end{array}$ & $\%$ \\
\hline $\begin{array}{c}\text { Jenis } \\
\text { Kelamin }\end{array}$ & & & $\begin{array}{c}\text { Kota } \\
\text { tempat } \\
\text { melakuk } \\
\text { an kuliah } \\
\text { daring }\end{array}$ & & \\
\hline Laki-laki & 13 & $\begin{array}{l}23, \\
63\end{array}$ & $\begin{array}{c}\text { Banjarma } \\
\sin \end{array}$ & 40 & $\begin{array}{l}72 \\
, 7 \\
2\end{array}$ \\
\hline $\begin{array}{c}\text { Perempu } \\
\text { an }\end{array}$ & 42 & $\begin{array}{l}76, \\
36\end{array}$ & $\underset{\mathrm{u}}{\text { Banjarbar }}$ & 1 & $\begin{array}{l}1, \\
81\end{array}$ \\
\hline$\underset{\text { (tahun) }}{\text { Usia }}$ & & & & & \\
\hline 17 & 1 & $\begin{array}{c}1,8 \\
1\end{array}$ & Ampah & 1 & $\begin{array}{l}1, \\
81\end{array}$ \\
\hline 18 & 13 & $\begin{array}{l}23, \\
63\end{array}$ & Birayang & 1 & $\begin{array}{l}1, \\
81\end{array}$ \\
\hline 19 & 21 & $\begin{array}{l}38 \\
18\end{array}$ & Buntok & 1 & $\begin{array}{l}1, \\
81\end{array}$ \\
\hline 20 & 11 & 20 & $\begin{array}{c}\text { Hulu } \\
\text { Sungai } \\
\text { Tengah }\end{array}$ & 4 & $\begin{array}{l}7, \\
27\end{array}$ \\
\hline 21 & 6 & $\begin{array}{c}10 \\
9\end{array}$ & Kotabaru & 2 & $\begin{array}{l}3, \\
63\end{array}$ \\
\hline 23 & 1 & $\begin{array}{c}1,8 \\
1\end{array}$ & $\begin{array}{c}\text { Tewang } \\
\text { Karangan }\end{array}$ & 1 & $\begin{array}{l}1, \\
81\end{array}$ \\
\hline 24 & 1 & $\begin{array}{c}1,8 \\
1\end{array}$ & $\begin{array}{l}\text { Tamiang } \\
\text { Layang }\end{array}$ & 1 & $\begin{array}{l}1, \\
81\end{array}$ \\
\hline 35 & 1 & $\begin{array}{c}1,8 \\
1\end{array}$ & $\begin{array}{l}\text { Kuala } \\
\text { Kapuas }\end{array}$ & 3 & $\begin{array}{l}5, \\
45\end{array}$ \\
\hline \multicolumn{6}{|l|}{$\begin{array}{c}\text { Angkata } \\
n\end{array}$} \\
\hline 2019 & 26 & $\begin{array}{l}47, \\
27\end{array}$ & & & \\
\hline 2020 & 29 & $\begin{array}{l}52 \\
72\end{array}$ & & & \\
\hline
\end{tabular}


Jurnal Media

Teknik dan

Sistem Industri

Pada Tabel II dapat dilihat mahasiswa pada saat mengikuti perkuliahan daring lebih banyak menggunakan smartphone yaitu sebanyak 39 orang $(70,9 \%)$ dan laptop sebanyak 16 orang mahasiswa $(29,09 \%)$. Mayoritas mengikuti perkuliahan di kost/kontrakan/asrama sebanyak 27 orang $(49,09 \%)$ tepatnya di kamar tidur sebanyak 40 orang $(72,72 \%)$. Pelaksanaan kuliah daring antara 2-4 kali $(49,09 \%)$ dalam seminggu dengan durasi perkuliahan 1-3 jam (87,27\%). Mayoritas responden menggunakan laptop atau smartphone adalah untuk mengikuti perkuliahan daring sebanyak 23 orang mahasiswa $(41,81 \%)$. Dan setelah penggunaan laptop atau smartphone per 2 jam, sebanyak 36 orang mahasiswa $(65,45 \%)$ melakukan peregangan otot selama 15 menit.

Responden selama mengikuti perkuliahan daring, memiliki perilaku seperti pada tabel di bawah ini :

TABEL II

PERILAKU RESPONDEN (MAHASISWA) SELAMA MENGIKUTI PERKULIAHAN DARING

\begin{tabular}{|c|c|c|c|c|c|}
\hline Variabel & $\begin{array}{c}\text { Juml } \\
\text { ah }\end{array}$ & $\%$ & Variabel & $\begin{array}{c}\text { Juml } \\
\text { ah }\end{array}$ & $\%$ \\
\hline $\begin{array}{c}\text { Gadget } \\
\text { yang } \\
\text { digunaka } \\
\text { n saat } \\
\text { perkuliah } \\
\text { an daring }\end{array}$ & & & $\begin{array}{c}\text { Mayorita } \\
\text { s } \\
\text { penggun } \\
\text { aan } \\
\text { laptop } \\
\text { atau } \\
\text { smartpho } \\
\text { ne }\end{array}$ & & \\
\hline $\begin{array}{c}\text { Smartphon } \\
e\end{array}$ & 39 & $\begin{array}{c}70, \\
9\end{array}$ & $\begin{array}{c}\text { Mengikut } \\
\mathrm{i} \\
\text { perkuliah } \\
\text { an daring }\end{array}$ & 23 & $\begin{array}{c}41,8 \\
1\end{array}$ \\
\hline Laptop & 16 & $\begin{array}{c}29 \\
09\end{array}$ & $\begin{array}{c}\text { Browsing } \\
\text { di google } \\
\text { Youtube } \\
\text { Games }\end{array}$ & $\begin{array}{l}4 \\
5 \\
4\end{array}$ & $\begin{array}{l}7,27 \\
9,09 \\
7,27\end{array}$ \\
\hline $\begin{array}{c}\text { Tempat } \\
\text { mengikuti } \\
\text { perkuliah } \\
\text { an daring }\end{array}$ & & & $\begin{array}{c}\text { Melakuk } \\
\text { an } \\
\text { peregang } \\
\text { an otot } \\
15 \text { menit } \\
\text { setelah } \\
\text { setiap } 2 \\
\text { jam } \\
\text { depan } \\
\text { laptop } \\
\text { atau } \\
\text { smartpho } \\
\text { ne }\end{array}$ & & \\
\hline $\begin{array}{c}\text { Kost/kontr } \\
\text { akan/asra } \\
\text { ma }\end{array}$ & 27 & $\begin{array}{l}49 \\
09\end{array}$ & $\mathrm{Ya}$ & 36 & $\begin{array}{c}65,4 \\
5\end{array}$ \\
\hline $\begin{array}{l}\text { Rumah } \\
\text { sendiri }\end{array}$ & 23 & $\begin{array}{l}41, \\
81\end{array}$ & Tidak & 19 & $\begin{array}{c}34,5 \\
4\end{array}$ \\
\hline $\begin{array}{c}\text { Rumah } \\
\text { teman/kelu } \\
\text { arga }\end{array}$ & 5 & $\begin{array}{c}9,0 \\
9\end{array}$ & & & \\
\hline $\begin{array}{c}\text { Ruangan } \\
\text { yang } \\
\text { diperguna }\end{array}$ & & & $\begin{array}{l}\text { Durasi } \\
\text { setiap }\end{array}$ & & \\
\hline
\end{tabular}

\begin{tabular}{|c|c|c|c|c|c|}
\hline Variabel & $\begin{array}{c}\text { Juml } \\
\text { ah }\end{array}$ & $\%$ & Variabel & $\begin{array}{c}\text { Juml } \\
\text { ah }\end{array}$ & $\%$ \\
\hline $\begin{array}{l}\text { kan } \\
\text { mengikuti } \\
\text { perkuliah } \\
\text { an daring }\end{array}$ & & & $\begin{array}{c}\text { mata } \\
\text { kuliah }\end{array}$ & & \\
\hline $\begin{array}{l}\text { Kamar } \\
\text { tidur }\end{array}$ & 40 & $\begin{array}{l}72, \\
72\end{array}$ & $\begin{array}{c}\text { Antara 1- } \\
3 \text { jam }\end{array}$ & 48 & $\begin{array}{c}87,2 \\
7\end{array}$ \\
\hline $\begin{array}{c}\text { Ruang } \\
\text { tamu }\end{array}$ & 12 & $\begin{array}{l}21, \\
81\end{array}$ & $\begin{array}{c}\text { Di bawah } \\
1 \text { jam }\end{array}$ & 7 & $\begin{array}{c}12,7 \\
2\end{array}$ \\
\hline $\begin{array}{l}\text { Ruang } \\
\text { keluarga }\end{array}$ & 1 & $\begin{array}{c}1,8 \\
1\end{array}$ & & & \\
\hline Dapur & 1 & $\begin{array}{c}1,8 \\
1\end{array}$ & & & \\
\hline Teras & 1 & $\begin{array}{c}1,8 \\
1 \\
\end{array}$ & & & \\
\hline
\end{tabular}

\begin{tabular}{ccc}
$\begin{array}{c}\text { Frekuensi } \\
\text { perkuliah } \\
\text { an setiap } \\
\text { minggu }\end{array}$ & & \\
\hline Antara 2-4 & 27 & 49, \\
kali & & 09 \\
Antara 5-7 & 25 & 45, \\
kali & & 45 \\
Lebih dari & 3 & 5,4 \\
8 kali & & 5 \\
\hline
\end{tabular}

Mayoritas posisi mahasiswa selama mengikuti perkuliahan adalah menggunakan meja kecil dengan posisi duduk di lantai sebanyak 37 orang $(67,27 \%)$, menggunakan laptop maupun smartphone di meja dengan posisi duduk di kursi sebanyak 6 orang $(10,9 \%)$, posisi menaruh laptop maupun smartphone di kaki atau di lantai sebanyak 6 orang $(10,9 \%)$, posisi dengan tengkurap di kasur sebanyak 4 orang $(7,27 \%)$, mengganti posisi (dari posisi duduk di kursi dan apabila lelah mengganti posisi menjadi tengkurap di kasur) sebanyak 2 orang $(3,63 \%)$.

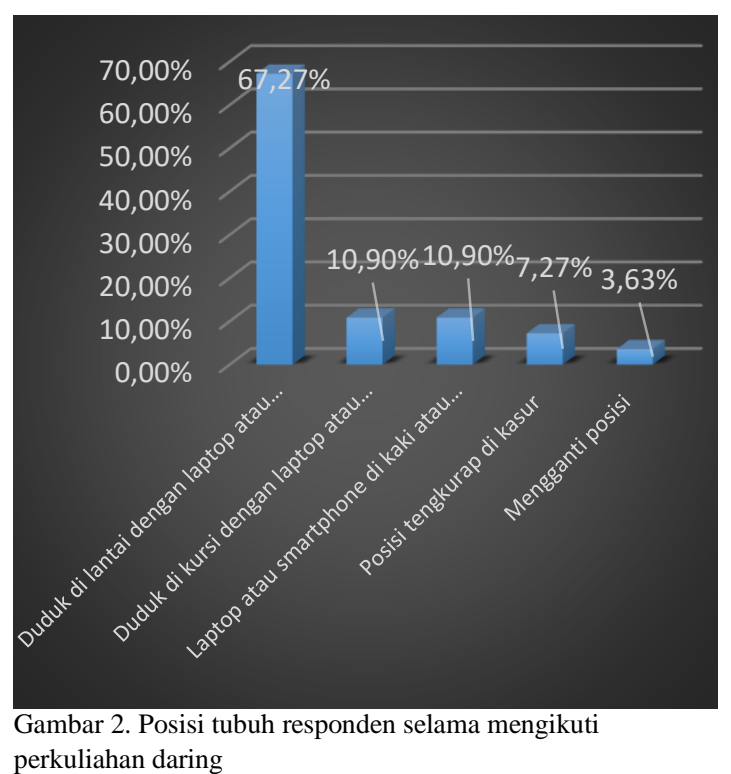

Berdasarkan hasil survey daring, hampir semua responden mengalami keluhan pada mata selama 
menggunakan laptop atau smartphone. Keluhan kelelahan mata yang paling banyak dialami oleh responden adalah mata perih sebanyak 35 orang mahasiswa $(63,63 \%)$. Kemudian diikuti keluhan sakit kepala sebanyak 34 orang $(61,81 \%)$ dan mata berair sebanyak 23 orang $(41,81 \%)$. Pada Tabel III dapat dilihat lebih rinci keluhan kelelahan mata yang dialami oleh responden.

TABEL III

KELUHAN KELELAHAN MATA RESPONDEN

\begin{tabular}{ccc}
\hline Jenis Keluhan & $\begin{array}{c}\text { Total } \\
\text { Responden }\end{array}$ & Persentase \\
\hline $\begin{array}{c}\text { Mata } \\
\text { nyeri/berdenyut } \\
\text { di sekitar mata } \\
\text { Penglihatan } \\
\text { kabur }\end{array}$ & 18 & 32,72 \\
$\begin{array}{c}\text { Penglihatan } \\
\text { rangkap/ganda }\end{array}$ & 2 & 27,27 \\
\end{tabular}

\begin{tabular}{ccc}
\hline Jenis Keluhan & $\begin{array}{c}\text { Total } \\
\text { Responden }\end{array}$ & Persentase \\
\hline Sulit fokus & 20 & 36,36 \\
Mata perih & 35 & 63,63 \\
Sakit kepala & 34 & 61,81 \\
Pusing serta & 5 & 9,09 \\
mual & & \\
Mata merah & 7 & 12,72 \\
Mata berair & 23 & 41,81 \\
\hline
\end{tabular}

TABEL IV

JARAK MATA DENGAN LAYAR LAPTOP ATAU SMARTPHONE

\begin{tabular}{ccc}
\hline $\begin{array}{c}\text { Jarak Mata } \\
\text { dengan Layar } \\
(\mathbf{c m})\end{array}$ & $\begin{array}{c}\text { Total } \\
\text { Responden }\end{array}$ & Persentase \\
\hline$<10$ & 9 & 16,4 \\
$10-29,99$ & 13 & 23,6 \\
$30-49,9$ & 18 & 32,77 \\
$50-70$ & 14 & 25,5 \\
$>70$ & 1 & 1,8 \\
\hline
\end{tabular}

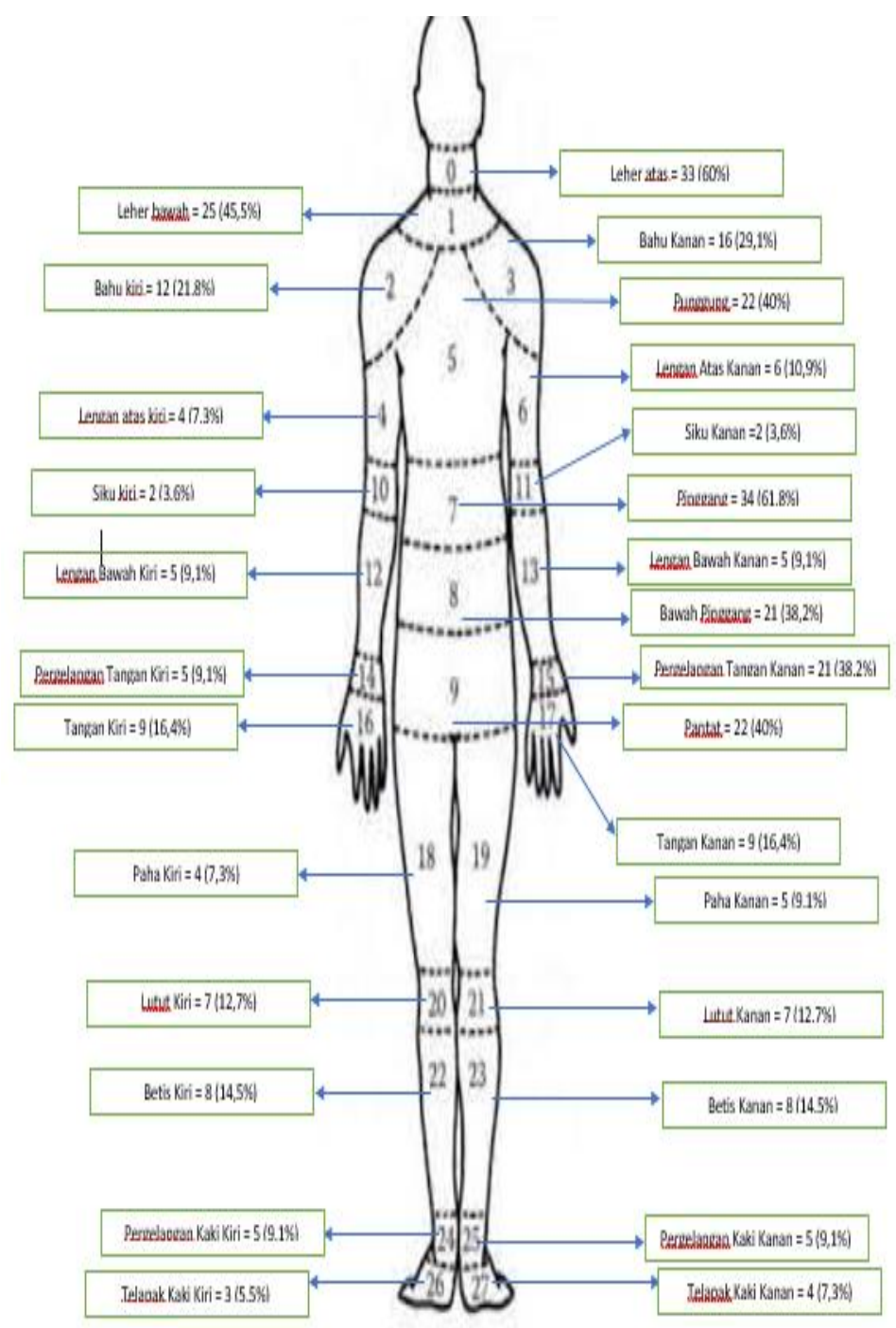

Gambar 3. Keluhan responden per bagian tubuh 


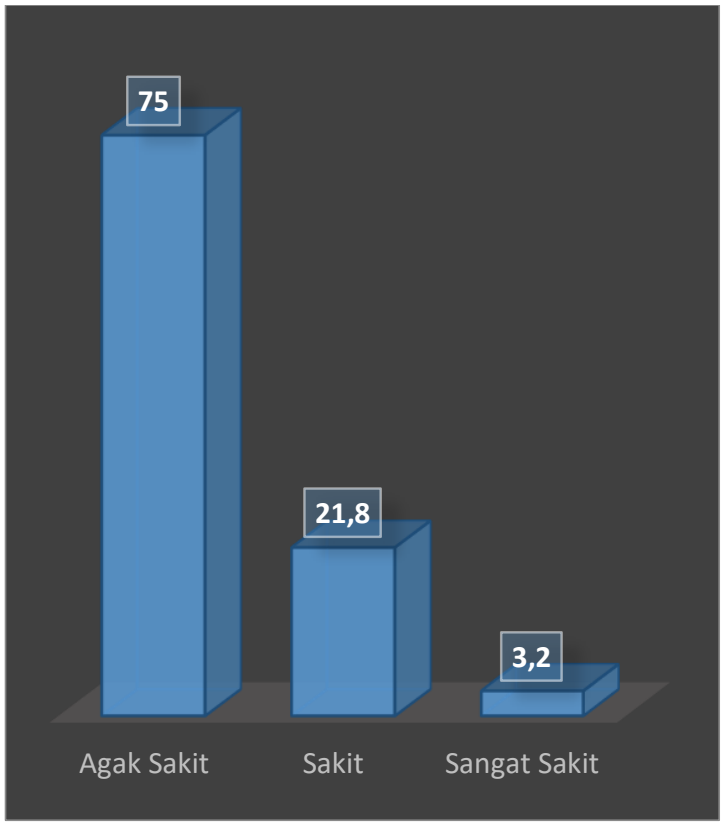

Gambar 4. Tingkat keparahan keluhan bagian tubuh

\section{PEMBAHASAN}

\section{A. Kelelahan Mata}

Dikutip dari NIOSH (dalam Monaliza et. all.), duduk terlalu lama atau durasi penggunaan komputer yang lebih dari batas maksimal akan berdampak terhadap kesehatan salah satunya keluhan pada mata. Pengguna komputer dianjurkan untuk mengistirahatkan mata selama menggunakan komputer. National Institute for Occupational Safety and Health (NIOSH) menyarankan untuk melakukan istirahat selama 15 menit terhadap pemakaian komputer selama 2 jam. Hal ini bertujuan untuk mengurangi kelelahan sehingga akan menambah kenyamanan lebih lama bagi pengguna komputer [15].

Mata secara terus-menerus berakomodasi untuk melihat huruf/angka pada monitor akan mengakibatkan kelelahan atau eyestrain. Dikutip dari Hanum adalah hal lain yang dapat menyebabkan kelelahan mata adalah jarak mata terlalu dekat dengan monitor, sehingga mata dipaksa bekerja untuk melihat dari jarak yang cukup dekat dalam jangka waktu yang lama. Occupational Safety and Health Association (OSHA) menyebutkan disebutkan bahwa jarak mata terhadap layar monitor sekurang-kurangnya adalah 20-40 inci atau 50-100 $\mathrm{cm} \mathrm{[15].}$

Dari kuesioner yang disebarkan kepada mahasiswa (bisa dilihat pada Tabel IV), jarak antara mata dengan layar laptop atau smartphone 30-49,99 cm sebanyak 18 orang $(32,77 \%)$, antara $10-29,99$ $\mathrm{cm}$ sebanyak 13 orang $(23,6 \%)$, antara $50-70 \mathrm{~cm}$ sebanyak 14 orang $(25,5 \%)$, lebih dari $70 \mathrm{~cm}$ sebanyak 1 orang $(1,8 \%)$ dan kurang dari $10 \mathrm{~cm}$ sebanyak 9 orang $(16,4 \%)$. Dengan data tersebut jika ditinjau dari standar yang ditetapkan oleh OSHA, maka mahasiswa berisiko untuk mengalami kelelahan mata.

Alasan atau penyebab utama terjadinya kelelahan mata yaitu jarak mata yang terlalu dekat dengan monitor, sehingga mata dipaksa bekerja untuk melihat dari jarak yang cukup dekat dalam jangka waktu yang cukup lama. Sedangkan fungsi mata sendiri sebenarnya tidak dikhususkan untuk melihat dari jarak dekat. Jarak pandang mata ke layar monitor usahakan jangan terlalu jauh atau terlalu dekat karena menyebabkan mata menjadi cepat lelah. Pengaturan jarak pandang mata yang tepat akan membuat tenaga kerja nyaman bekerja dan menjaga kesehatan mata [16].

Bila melihat Tabel III di atas, semua keluhan visual fatigue dialami oleh responden. Hal ini sejalan dengan pernyataan Sheedy dalam [17] yang menyatakan bahwa suatu studi dari 64\% sampai 90\% pengguna komputer mengalami Computer Vision Syndrome (CVS) [10]. Menggunakan komputer selama lebih dari 4 jam sekaligus dapat meningkatkan ketidaknyamanan mata secara signifikan. Mahasiswa sebagai responden yang berada di depan komputer maupun smartphone selama lebih dari 4 jam hampir 50\%. Kondisi dengan durasi depan komputer atau smartphone, selain mengikuti perkuliahan daring, juga banyak digunakan untuk mengakses media sosial. Selain itu, sindrom lelah visual lebih sering terjadi pada mereka yang bekerja dengan komputer dan telah dilaporkan pada hingga $60 \%$ individu yang bekerja dengan monitor video [16].

Gejala CVS atau kelelahan mata terjadi ketika kebutuhan visual meningkat akan tetapi tidak diimbangi kemampuan visual individu yang bersangkutan. Gambar pada layar komputer atau laptop diproduksi oleh ribuan pixel yang membentuk suatu gambar di mana margin tidak tajam dan tergantung kepada resolusi, kontras latar belakang, dan silau atau pantulan dari layar sehingga berkontribusi terhadap meningkatnya kelelahan mata [17].

Durasi penggunaan perangkat seluler pintar telah mencapai tingkat yang sangat tinggi di generasi muda. Paparan harian yang terus menerus dengan smartphone (lebih dari 2 jam per hari) merupakan faktor risiko yang sangat signifikan untuk menyebabkan berbagai jenis ketidaknyamanan mata. Masalah kesehatan mata yang mungkin disebabkan oleh penggunaan perangkat seluler pintar yang intens mungkin tidak terbatas pada masalah permukaan mata seperti mata kering dan disfungsi air mata, tetapi juga dapat mempengaruhi jaringan saraf retina. Penggunaan 
komputer setiap hari selama 3 jam juga dapat menyebabkan risiko keluhan visual yang semakin meningkat [13].

\section{B. Keluhan MSDs}

Pada gambar 3, dapat terlihat keseluruhan keluhan responden per bagian tubuh mulai dari leher atas sampai telapak kaki kanan. Sedangkan untuk tingkat keparahan keluhan dapat dilihat pada gambar 4. Tingkat keparahan keluhan mulai dari agak sakit sebesar $75 \%$, sakit sebesar $21,8 \%$ dan sangat sakit 3,2\%.

Mayoritas keluhan MSDs yang dialami oleh mahasiswa adalah pada bagian pinggang sebanyak 34 orang $(61,8 \%)$, pada bagian leher atas sebanyak 33 orang $(60 \%)$ dan pada bagian leher bawah sebanyak 25 orang $(45,5 \%)$. Gambar 5 memberi deskripsi lima keluhan pada bagian tubuh yang paling banyak dialami oleh responden (mahasiswa).

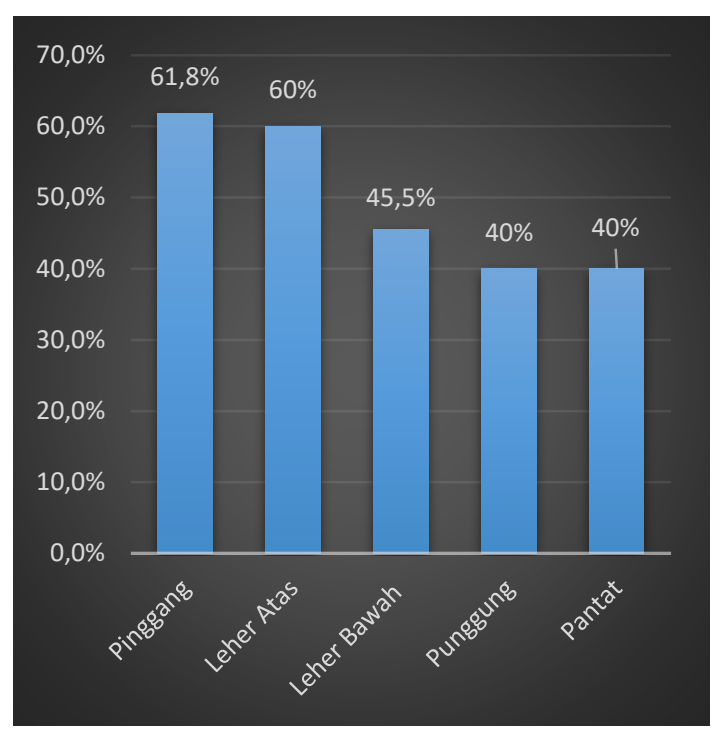

Gambar 5. Keluhan MSDs yang dialami oleh responden

Bila melihat posisi mahasiswa ketika mengikuti perkuliahan daring, maka yang paling banyak adalah dengan posisi memakai laptop atau smartphone dengan duduk di lantai. Posisi ini adalah posisi kerja yang tidak ergonomis. Dan lima keluhan pada bagian tubuh yang paling banyak dialami oleh mahasiswa dengan posisi duduk di lantai adalah keluhan pada bagian pinggang 22 orang $(10,68 \%)$, leher atas 21 orang $(10,19 \%)$, leher bawah 20 orang $(9,71 \%)$, punggung 16 orang $(7,76 \%)$ dan bawah pinggang 16 orang $(7,76 \%)$.

Berdasarkan gambar 6, mahasiswa yang duduk dilantai memiliki perilaku yang tidak ergonomis. Hal ini dapat mengganggu kesehatan dengan adanya keluhan pada bagian pinggang. Dengan tidak adanya kursi yang disertai sandaran pada punggung, akan berakibat semakin meningkatnya keluhan MSDs. Hasil penelitian ini didukung oleh penelitian pada mahasiswa Teknik Informatika di mana mahasiswa menggunakan laptop dengan posisi duduk di lantai yaitu sebanyak 26 orang mahasiswa $(49,1 \%)$. Hal tersebut merupakan perilaku yang negatif yang sangat mengganggu jika dilakukan terus menerus dan perlu adanya perubahan perilaku. Perilaku negatif ini juga menyebabkan posisi kepala menunduk ke depan, terlalu condong ke kanan atau ke kiri, sikap duduk yang salah posisi statis dalam waktu yang lama [3].

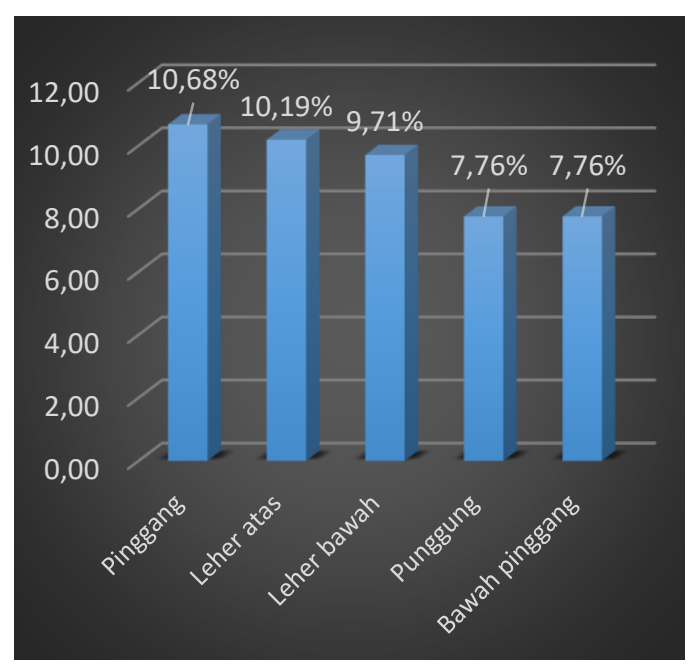

Gambar 6. Keluhan MSDs dengan posisi laptop atau smartphone di meja dan duduk di lantai

Hasil penelitian yang sama pada sekelompok profesional dengan posisi bekerja dengan tidak ergonomis melakukan pekerjaan dari rumah karena pandemi yang mengalami keluhan nyeri pada bagian leher $(36,9 \%)$ dan bagian punggung bawah $(34,6 \%)$. Sekelompok profesional ini bekerja dengan menggunakan laptop dengan durasi bekerja depan laptop $\geq 4$ jam [18].

Untuk tingkat keluhan pada mahasiswa pada saat mengikuti perkuliahan daring dengan posisi duduk di kursi dapat dilihat gambaran besarnya pada gambar 7. Pada gambar 7 dapat dilihat mahasiswa yang mengalami keluhan pada bagian pinggang mengalami tingkat keluhan agak sakit sebanyak 12 orang $(54,55 \%)$, sakit sebanyak 9 orang $(40,91 \%)$ dan sangat sakit sebanyak 1 orang $(4,55 \%)$. Keluhan pada bagian leher atas, tingkat keluhan agak sakit sebanyak sebanyak 11 orang $(84,62 \%)$ dan sakit sebanyak 2 orang $(15,38 \%)$. 
Jurnal Media

Teknik dan

Sistem Industri

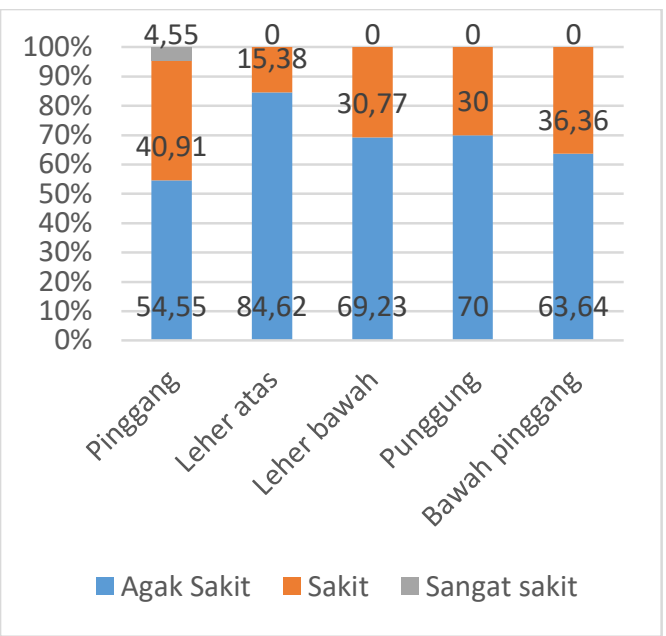

Gambar 7. Tingkat keluhan MSDs dengan posisi laptop atau smartphone di meja dan duduk di kursi

Sedangkan keluhan pada mahasiswa yang duduk di kursi dengan laptop atau smartphone di meja adalah pada bagian pinggang $(15,15 \%)$, leher atas $(12,12 \%)$, pantat $(12,12 \%)$, punggung $(12,12 \%)$ dan leher bawah $(6,06 \%)$. Dapat dilihat pada gambar 8 .

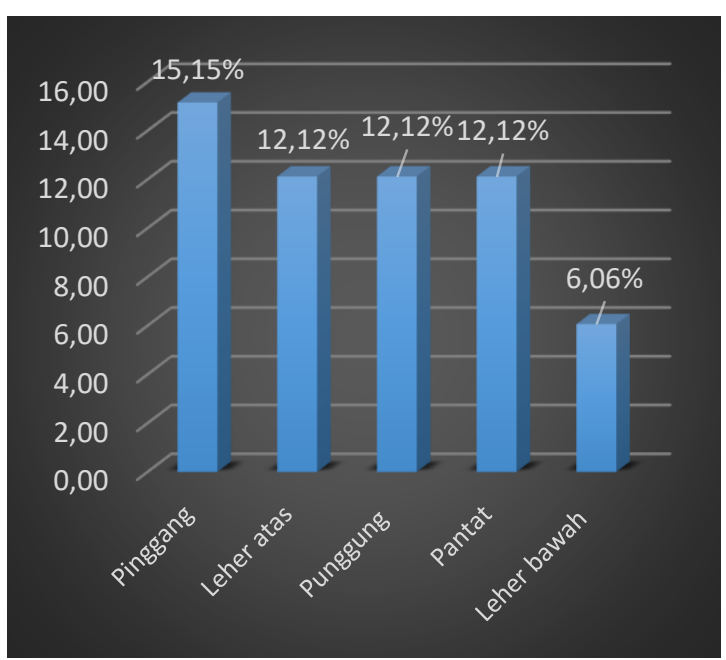

Gambar 8. Keluhan MSDs dengan posisi laptop atau smartphone di meja dan duduk di kursi

Mahasiswa sebagai responden memiliki kemungkinan posisi meja yang terlalu rendah daripada kursi. Sehingga memaksa tubuh untuk membungkuk mendekati meja sehingga berdampak pada keluhan rasa sakit pada bagian leher atas dan leher bawah. Sedangkan untuk keluhan bagian pantat dikarenakan kursi yang dimiliki oleh mahasiswa tidak menggunakan busa.

Keluhan yang sama juga dirasakan oleh akademisi bagian pengajaran dan penelitian dan staf Universitas Newcastle di mana mereka bekerja dengan menggunakan laptop atau komputer. Sebelum adanya intervensi pelatihan ergonomi, responden merasakan ketidaknyamanan pada bagian leher (59\%), bahu (53\%), punggung (47\%) [19].

Dikutip dari hasil penelitian Santoso (dalam Septy, et. all.), pada saat mengoperasikan laptop dengan posisi duduk otot rangka (musculoskeletal) dan tulang belakang (Vertebral) terutama bagian pinggang (sacrum, lumbal, dan thorakal) harus ditahan oleh sandaran pada bagian kursi dan agar kondisi tubuh tidak cepat lelah (fatigue). Menurut hasil dan teori di atas peneliti berpendapat bahwa sangat penting mengistirahatkan tubuh saat menggunakan laptop karena memaksakan tubuh saat kelelahan dapat menurunkan produktivitas. Menggunakan meja dan kursi yang terdapat penyangga punggung sangat penting untuk membuat tubuh tetap tegak dan nyaman saat menggunakan laptop.

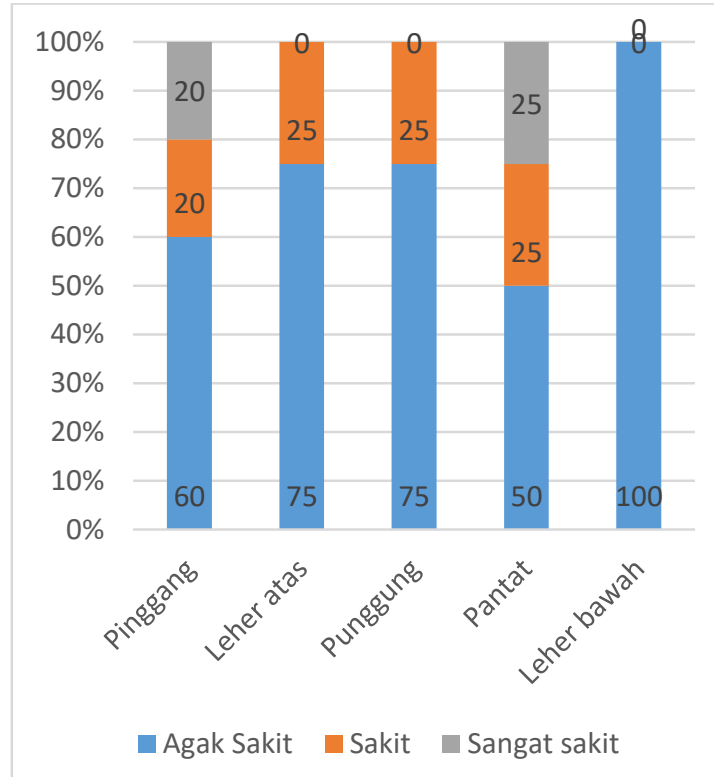

Gambar 9. Tingkat keluhan MSDs dengan posisi laptop atau smartphone di meja dan duduk di kursi

Tingkat keluhan pada mahasiswa pada saat mengikuti perkuliahan daring dengan posisi duduk di kursi dapat dilihat gambaran besarnya pada gambar 9. Pada gambar 9 dapat dilihat mahasiswa yang mengalami keluhan pada bagian pinggang mengalami tingkat keluhan agak sakit sebanyak 3 orang $(60 \%)$, sakit sebanyak 1 orang $(20 \%)$ dan sangat sakit sebanyak 1 orang $(20 \%)$. Keluhan pada bagian leher atas, tingkat keluhan agak sakit sebanyak sebanyak 3 orang (75\%) dan sakit sebanyak 1 orang $(25 \%)$.

Bila dilihat hasil kuesioner mahasiswa, sebanyak 28 orang $(70 \%)$ melaksanakan perkuliahan daring tidak menggunakan kursi yang memiliki sandaran atau penyangga. Dan apabila ditarik dengan hasil penelitian Santoso, maka 
keluhan MSDs yang dirasakan oleh mahasiswa sebagai akibat dari penggunaan kursi yang tidak memiliki sandaran atau penyangga. Hal ini berdampak pada tubuh mahasiswa cepat mengalami kelelahan (fatigue).

\section{KESIMPULAN}

Hampir keseluruhan responden mengalami kelelahan mata seperti mata perih, sakit kepala dan mata berair. Penelitian ini juga menunjukkan hampir semua responden mengalami keluhan MSDs pada bagian tubuh. Mayoritas keluhan responden pada bagian tubuh pinggang, leher atas, leher bawah, punggung dan pantat. Sedangkan untuk keluhan dengan posisi selama mengikuti perkuliahan daring adalah dengan penggunaan laptop maupun smartphone di meja dan duduk di lantai.

Adapun kelemahan dari penelitian ini adalah pelaksanaan penelitian tidak dilakukan di tempat mahasiswa melaksanakan perkuliahan daring karena adanya pandemi Covid-19. Untuk penelitian selanjutnya terutama untuk mengetahui tingkat keparahan postur tidak normal (sebagai data pendukung keluhan MSDs dengan menggunakan metode RULA), penelitian sebaiknya dilakukan dengan melihat langsung pembelajaran daring mahasiswa. Selain itu, penelitian ini tidak dilakukan pada keseluruhan mahasiswa yang ada di Universitas Sari Mulia.

Agar mahasiswa dapat mengurangi keluhan $M S D s$ dan kelelahan mata, maka beberapa saran di bawah ini yang dapat dilakukan :

1. Setiap 20 menit setelah menggunakan laptop atau smartphone dapat mengalihkan pandangan ke objek lain.

2. Mengganti kursi yang tidak memiliki penyangga punggung dengan kursi yang memiliki penyangga punggung.

3. Pemakaian laptop atau smartphone diusahakan sejajar dengan mata untuk menghindari posisi leher menunduk.

4. Melakukan beberapa peregangan kecil di selasela istirahat.

\section{REFERENSI}

[1] Kementerian Kesehatan RI, Pedoman Pencegahan Dan Pengendalian Corona Virus Disease (Covid-19). Jakarta, 2020.

[2] A.D. Minghat, A. Ana, P. Purnawarman, S. Saripudin, M. Muktiarni, V. Dwiyanti, dan S.S. Mustakim, "Students Perceptions of the Twists and Turns of E-learning in the Midst of the Covid 19 Outbreak," Revista Romaneasca pentru Educatie Multidimensionala, vol.12, no. 5, pp. 1526, 2020.

[3] S. Wahyuningtyas, L. Isro'in, dan S. Maghfirah, "Hubungan Antara Perilaku Penggunaan Laptop Dengan Keluhan Musculosceletal Disorder (MSDS) Pada Mahasiswa Teknik Informatika," Prosiding Arah
Kebijakan dan Optimalisasi Tenaga Kesehatan Menghadapi Revolusi Industri 4.0, pp. 196-206, 2019.

[4] S. Lee, Y.H. Choi, dan J. Kim, "Effects of the Cervical Flexion Angle During Smartphone Use on Muscle Fatigue and Pain in the Cervical Erector Spinae and Upper Trapezius in Normal Adults in Their 20s," J Phys Ther Sci, vol.29, no.5, pp. 921-923, 2017.

[5] H. Muchtar, N. Sahara, "Hubungan Lama Penggunaan Laptop Dengan Timbulnya Keluhan Computer Vision Syndrome (CVS) Pada Mahasiswa/I Fakultas Kedokteran Umum Universitas Malahayati," Jurnal Medika Malahayati, vol.3, no.4, pp. 197-203, 2016.

[6] M.H. Wea, S.O. Batubara, dan A. Waluyo, "Hubungan Tingkat Penggunaan Smartphone Dengan Kejadian Miopia Pada Mahasiswa Keperawatan Angkatan VII STIKES Citra Husada Mandiri Kupang," CHMK Applied Scientific Journal, vol.1. no.1, pp. 11-17, 2018.

[7] B.P. Dandumahanti, M. Subramaniyam, "A Systematic Review on Visual Fatigue Induced by Tiny Screens (Smartphones)," 3rd International Conference on Advances in Mechanical Engineering (ICAME 2020), vol. 912, pp. 1-9, 2020.

[8] Tarwaka, et al, Keselamatan dan Kesehatan Kerja dan produktivitas, Surakarta: UNIBA Press, 2004.

[9] S. Pheasant, Ergonomics, Work and Health. London : Macmillan Press, 1991.

[10] P.K. Suma'mur, Higiene Perusahaan dan Kesehatan Kerja (Hiperkes), Edisi Kedua. Jakarta: CV. Agung Seto, 2013.

[11] S. Arikunto, Prosedur Penelitian : Suatu Pendekatan Praktik, Edisi Revisi VI. Jakarta : PT. Rineka Cipta, 2006.

[12] A.G. Abudawood, H.M.Ashi, N.K. Almarzouki, "Computer Vision Syndrom among Undergraduate Medical Students in King Abdulaziz University, Jeddah, Saudi Arabia," Journal of Ophthalmology, vol. 2020, pp. 1-7, 2020.

[13] M.S. Sirajudeen, H. Muthusamy, M. Alqahtani, M. Waly, J. Mohamed, dan A.K. Jilani, "Computer Related Health Problems Among University Students In Majmaah Region, Saudia Arabia," Biomedical Research, vol. 29, no. 11, pp. 2405-2415, 2018.

[14] L.F. Selisca, "Faktor-Faktor yang Berhubungan dengan Keluhan Mata pada Pengguna Komputer di Accounting Group PT Bank X Jakarta” Jakarta: Skripsi, 2013.

[15] Monaliza, D, Karim, dan S.R.H. Damanik, "Faktor-Faktor yang Berhubungan dengan Keluhan Computer Vision Syndrome (CVS) pada Mahasiswa Keperawatan Universitas Riau," JOM FKP, vol. 5, no. 2, pp. 146-154, 2018.

[16] R.Asnel, C.Kurniawan, "Analisis Faktor Kelelahan Mata pada Pekerja Pengguna Komputer," Jurnal Endurance : Kajian Ilmiah Problema Kesehatan, vol.5 no. 2, pp. 356365, 2020.

[17] D.J. Kim, C.Y. Lim, N.Gu, dan C.Y. Park, "Visual Fatigue Induced by Viewing a Tablet Computer wirh a High Resolution Display," Korean J Ophthalmol, vol.31, no.5, pp. 388-393, 2017.

[18] T.D Vora, "A Survey Of Musculoskeletal Symptoms Associated With Work From Home Culture In Covid-19," International Journal Of Scientific Research, vol. 9, no.9, pp. 1-2, 2020.

[19] James, D. James, V. Nie, T. Schumaher, et al, "Musculoskeletal Discomfort and Use of Computers in The University Environment," Applied Egonomics, vol. 69, pp. 128-135, 2018 